\title{
Dietary sodium and arterial blood pressure: evidence against genetic susceptibility
}

\author{
G C M WATT, C J W FOY, J T HART, GEORGINA BINGHAM, CATHERINE EDWARDS, \\ MARY HART, EVELYN THOMAS, PAM WALTON
}

\begin{abstract}
Thirty five subjects with both parents in the top third of their age specific blood pressure distributions and 31 subjects with both parents in the bottom third of their blood pressure distributions restricted their intake of sodium for eight weeks while taking part in a double blind, randomised crossover trial of supplements of sodium and placebo. A comparison of two periods of four weeks at different intakes of sodium showed no differences in blood pressure in either the groups as a whole or the subgroups who complied best with the diet and tablets. In the compliant subgroups mean urinary sodium excretions were above $120 \mathrm{mmol}(\mathrm{mEq})$ and below $50 \mathrm{mmol} / \mathrm{day}$.

The study provides evidence against the hypothesis that people with a family history of high blood pressure are more susceptible in their blood pressure response to dietary sodium.
\end{abstract}

\section{Introduction}

One explanation for the failure to show a consistent association between dietary sodium and arterial pressure within single populations is that people vary in their genetic susceptibility to dietary sodium. ${ }^{12}$ The evidence supporting this explanation is based mostly on comparisons of handling sodium by cells and organs in young persons with and without a family history of high blood pressure..$^{3.10}$

\footnotetext{
Glyncorrwg Health Centre, West Glamorgan, and Medical Research Council Epidemiology and Medical Care Unit, Northwick Park Hospital, Middlesex G C M WATT, MRCP, research registrar C J W FOY, MSC, statistician

J T HART, FRCGP, MRCP, general practitioner GEORGINA BINGHAM, BSC, SRD, dietitian CATHERINE EDWARDS, research assistant MARY HART, senior research assistant EVELYN THOMAS, research assistant PAM WALTON, research assistant
}

Correspondence and requests for reprints to: Dr G C M Watt, MONICA Project, Royal Infirmary, Glasgow.
Few studies have included data on sodium intake. ${ }^{112}$ We set out to investigate within a single population whether the contrasting predispositions to high blood pressure of offspring with and without a family history could be explained by variation in susceptibility to dietary sodium.

In our first study, comparing 116 offspring with parents either both from the top (high/high) or both from the bottom (low/low) of the blood pressure distribution in their five year age group, high/high offspring had significantly higher systolic blood pressures than low/low offspring, but there was no significant difference in body weight, plasma renin activity, or 24 hour excretion of urinary electrolytes or creatinine. ${ }^{13}$ Both groups had high sodium intakes, however, and the results did not exclude the hypothesis that high/high offspring are more susceptible than low/low offspring to high sodium intake. To test this hypothesis directly we conducted an experiment in both groups of offspring, comparing blood pressure at two levels of sodium intake sustained over four weeks. Ideally these levels would be below $50 \mathrm{mmol}(\mathrm{mEq})$ and above $120 \mathrm{mmol} / \mathrm{day}$, corresponding with sodium intakes associated with a low and high prevalence of hypertension in different populations. ${ }^{14-16}$

\section{Subjects and methods}

A detailed description of the sampling method has been published. ${ }^{13}$ The base population consisted of 1069 adults aged $25-69$, representing the entire population in this age range of the mining village of Glyncorrwg in south Wales, an area with high stroke and coronary mortality. ${ }^{17}$ These adults had all had their blood pressure measured on at least one but usually several occasions during the previous five years as part of a community blood pressure control programme. ${ }^{18}$ Ninety one patients were receiving hypotensive treatment for diastolic pressures sustained above $104 \mathrm{~mm} \mathrm{Hg}$ (mean of three measurements, diastolic phase V; changed to $99 \mathrm{~mm} \mathrm{Hg}$ in 1981).

Marriages were identified between spouses either both from the top (high/high) or both from the bottom (low/low) third of the blood pressure distribution in their five year age group; treated hypertensive patients being added to the top of their age-sex distribution. There were 73 such marriages, including $32 \mathrm{low} / \mathrm{low}$ and $35 \mathrm{high} / \mathrm{high}$ families, with 170 offspring aged 10 or over and related to both parents. Of these offspring, 129 lived locally.

As parents had been classified on the basis of routine data from the health centre their blood pressure was measured again six times under standard 
conditions. These data confirmed the large difference in blood pressure (about $40 / 20 \mathrm{~mm} \mathrm{Hg}$ ) between groups of parents selected in this way. High/high parents were also heavier. ${ }^{6}$

For practical reasons we decided to confine the second study, with one exception, to the 98 offspring ( 44 low/low, 54 high/high) who lived locally and had complied with the first study. Recruitment stopped when all the low/low offspring had been approached and the number of compliant high/high offspring was sufficient for the statistical requirements of the study. In all 84 were approached, 75 agreed to take part, and 66 completed the study. The group that completed the study comprised 31 low/low offspring (14 men, 17 women, mean age $22 \cdot 7$ years) and $35 \mathrm{high} / \mathrm{high}$ offspring ( 13 men, 22 women, mean age $22 \cdot 3$ years).

All offspring were asked to restrict their sodium intake for eight weeks while taking part in a double blind, randomised crossover trial of supplements of sodium and placebo. Participants were asked not to add salt to their food, to use as little salt as possible in cooking, and to avoid salty foods. There were no other dietary restrictions or advice. Each household was given a shopping guide, a list of local recipes adapted for low sodium cooking, and a wall poster indicating, for each meal of the day, which foods should be avoided, taken in moderation, or eaten freely. In addition, each participant was provided with about $£ 12$ worth of foodstuffs weekly, including fruit, vegetables, low sodium bread, salt free butter, and a range of low sodium foodstuffs prepared by the research team. All participants were asked to carry on with their usual activities during the study. A special effort was made to anticipate and provide for the problems that they might have with sodium restriction at home, at school, at work, or on social occasions.
The crossover design is statistically powerful, and comparing four weeks with slow sodium with four weeks on placebo, with 18 people having two measurements of blood pressure a week, the study would have a $90 \%$ chance of detecting a true $3 \mathrm{~mm} \mathrm{Hg}$ difference in mean arterial pressure (diastolic and one third pulse pressure) in either direction using a paired $t$ test at the $5 \%$ level of significance. Estimates of the mean differences in blood pressure and other variables were obtained for the first and second four week periods and assessed for order effects before the effects of treatment were compared between the periods with slow sodium and placebo.

Ethical approval for the study was obtained from both the Glyncorrwg Health Centre patients' committee and the joint ethics committee, West Glamorgan Area Health Authority.

\section{Results}

The tables give data on all offspring who completed the study (completers) and those adjudged to have complied best with the diet and the tablets (compliers). Two arbitrary criteria of compliance were chosen before looking at the data on blood pressure. They were a mean 24 hour urinary sodium excretion below $100 \mathrm{mmol}$ during the period on placebo, indicating compliance with the diet, and a difference of at least $40 \mathrm{mmol}$ in mean 24 hour urinary sodium excretion between the two periods of the study, indicating compliance with the tablets.

Baseline measurements showed the same findings in relation to blood

TABLE I-Mean $(S D)$ baseline measurements

\begin{tabular}{|c|c|c|c|c|}
\hline & \multicolumn{2}{|c|}{ High/high } & \multicolumn{2}{|c|}{ Low/low } \\
\hline & Compliers $(n=26)$ & Completers $(n=35)$ & Compliers $(n=16)$ & Completers $(n=31)$ \\
\hline $\begin{array}{l}\text { Systolic blood pressure }(\mathrm{mm} \mathrm{Hg}) \\
\text { Diastolic blood pressure }(\mathrm{mm} \mathrm{Hg}) \\
\text { Mean arterial blood pressure }(\mathrm{mm} \mathrm{Hg}) \\
\text { Weight }(\mathrm{kg}) \\
24 \text { hour sodium excretion }(\mathrm{mmol}) \\
24 \text { hour potassium excretion }(\mathrm{mmol})\end{array}$ & $\begin{array}{r}113 \cdot 0(13 \cdot 2) \\
63 \cdot 9(11 \cdot 5) \\
80 \cdot 2(11 \cdot 3) \\
62 \cdot 5(15 \cdot 8) \\
127 \cdot 1(55 \cdot 1) \\
54 \cdot 9(16 \cdot 5)\end{array}$ & $\begin{array}{r}113 \cdot 1(13 \cdot 3) \\
65 \cdot 2(11 \cdot 2) \\
81 \cdot 1(11 \cdot 1) \\
64 \cdot 3(16 \cdot 7) \\
129 \cdot 7(55 \cdot 3) \\
53 \cdot 8(18 \cdot 9)\end{array}$ & $\begin{array}{r}108 \cdot 6(9 \cdot 0) \\
60 \cdot 9(7 \cdot 7) \\
76 \cdot 6(7 \cdot 0) \\
61 \cdot 3(12 \cdot 7) \\
140 \cdot 1(60 \cdot 2) \\
56 \cdot 7(19 \cdot 5)\end{array}$ & $\begin{array}{r}108 \cdot 8(11 \cdot 5) \\
61 \cdot 9(9 \cdot 5) \\
77 \cdot 5(8 \cdot 8) \\
64 \cdot 9(14 \cdot 5) \\
151 \cdot 1(63 \cdot 6) \\
60 \cdot 0(18 \cdot 3)\end{array}$ \\
\hline
\end{tabular}

Participants were allocated at random to four weeks of slow sodium tablets (10 mmol sodium/tablet) (Ciba) followed by four weeks of slow sodium placebo tablets (Ciba) or vice versa, with a fixed dose of eight tablets a day. The statistician randomised and labelled the containers of the tablets without calling on the research team at Glyncorrwg. The design of the study was carefully explained to each participant, but they did not know the number or timing of changeovers of tablets.

Blood pressure and weight were measured at 10 weekly afternoon clinics at the health centre, the first two clinics being used to establish baseline data. Each participant was seen on the same day of the week at the same time of day. Measurements of blood pressure were taken by three experienced Medical Research Council fieldworkers, who used random zero sphygmomanometers and large cuffs for obese arms. Blood pressure was measured twice in the left arm in the seated position after five minutes' rest. Recordings were taken to the nearest even number, diastolic phase V. Offspring started a 24 hour collection of urine with the second void on the day of their attendance at the clinic and completed it with the first void on the following day. Fourteen specimens of urine were omitted from analyses on account of admitted incompleteness. Urinary sodium and potassium concentrations were measured at the biochemistry department, Neath General Hospital. A 20\% random sample of specimens of urine was sent for duplicate analyses at the university department of biochemistry, Glasgow Royal Infirmary. No significant differences were observed between laboratories.

None of the offspring who completed the study was receiving hypotensive drugs or any drug that might interfere with the balance of sodium. One low/low and five high/high women were taking the contraceptive pill. No offspring had clinical evidence of cardiovascular, cerebrovascular, or renal disease.

Fieldwork took place in four stages between autumn 1982 and winter 1983. An attempt was made to balance the number of high/high and low/low offspring in each stage, but the final group had a preponderance of low/low offspring. Before fieldwork began an exercise was undertaken to compare readings of blood pressure obtained by the three observers. Fifteen subjects had their blood pressure measured by each of the observers in a random order. This showed close agreement between observers, with no two observers differing by more than $1 \mathrm{~mm} \mathrm{Hg}$ for the mean of all measurements taken. pressure, body weight, and urinary electrolyte excretion as had been observed with larger numbers in the first study (table I). Among the low/low and high/high offspring who completed the study there were no significant differences in blood pressure, body weight, urinary volume, or urinary electrolyte excretion between the baseline period and the first and second four weeks (table II)

For the low/low offspring who completed the study mean 24 hour urinary sodium excretion was $68 \mathrm{mmol}$ during the period on placebo (table III). There was a $60 \mathrm{mmol}$ difference in sodium excretion between the two periods of the study but no significant difference in blood pressure, body weight, or urinary potassium excretion. For the high/high offspring who completed the study mean 24 hour urinary sodium excretion was $56 \mathrm{mmol}$ during the period on placebo. There was a $74 \mathrm{mmol}$ difference in sodium intake between the two periods of the study but no significant difference in blood pressure, body weight, or urinary potassium excretion.

Of the 66 offspring who completed the study, 15 low/low and nine high/high offspring were non-compliant: eight with diet, 14 with the tablets, and two with both diet and tablets. Offspring who did not comply with the diet were heavier (mean $82.0 \mathrm{~kg}$ ) and had higher sodium intakes at the outset (mean $204 \mathrm{mmol}$ ). Many of them, in fact, achieved large reductions from their usual sodium intake. There were no obvious differences between offspring who complied with the tablets and those who did not.

In the low/low group 11 of those randomised to slow sodium first were later found to be non-compliant, compared with four of those randomised to placebo first. As a result the low/low compliant group contained a preponderance of those randomised to placebo first, which explains the increase in sodium excretion in the second four weeks in this group (table II). The other variables showed relatively small differences, suggesting that the analysis was not invalidated by the imbalance. For the 16 compliant low/low offspring, (six men, 10 women, mean age 23.9 years) mean 24 hour urinary sodium excretion was $49 \mathrm{mmol}$ during the period with placebo (table III). There was a difference of $77 \mathrm{mmol}$ in urinary sodium excretion between the two periods of the study but no significant difference in blood pressure, body weight, or 24 hour urinary potassium excretion. The $95 \%$ confidence interval for the difference in mean arterial pressure during the period with placebo ranged from $1.8 \mathrm{~mm} \mathrm{Hg}$ lower to $2.6 \mathrm{~mm} \mathrm{Hg}$ higher.

For the $26 \mathrm{high} / \mathrm{high}$ compliant offspring ( $10 \mathrm{men}, 16$ women, mean age 21.0 years) mean 24 hour urinary sodium excretion was $43 \mathrm{mmol}$ during the 


\begin{tabular}{|c|c|c|c|c|c|c|c|c|c|c|c|c|}
\hline & \multicolumn{6}{|c|}{ Low/low offspring } & \multicolumn{6}{|c|}{ High/high offspring } \\
\hline & \multicolumn{3}{|c|}{ Completers $(n=31)$} & \multicolumn{3}{|c|}{ Compliers $(n=16)$} & \multicolumn{3}{|c|}{ Completers $(n=35)$} & \multicolumn{3}{|c|}{ Compliers $(n=26)$} \\
\hline & $\begin{array}{c}\text { Weeks } \\
1-4\end{array}$ & $\begin{array}{c}\text { Weeks } \\
5-8\end{array}$ & $\begin{array}{c}\text { SE of } \\
\text { difference }\end{array}$ & $\begin{array}{c}\text { Weeks } \\
1-4\end{array}$ & $\begin{array}{c}\text { Weeks } \\
5.8\end{array}$ & $\begin{array}{c}\text { SE of } \\
\text { difference }\end{array}$ & $\begin{array}{c}\text { Weeks } \\
1-4\end{array}$ & $\begin{array}{c}\text { Weeks } \\
5-8\end{array}$ & $\begin{array}{c}\text { SE of } \\
\text { difference }\end{array}$ & $\begin{array}{c}\text { Weeks } \\
1-4\end{array}$ & $\begin{array}{c}\text { Weeks } \\
5-8\end{array}$ & $\begin{array}{c}\text { SE of } \\
\text { difference }\end{array}$ \\
\hline $\begin{array}{l}\text { Systolic blood pressure }(\mathrm{mm} \mathrm{Hg}) \\
\text { Diastolic blood pressure }(\mathrm{mm} \mathrm{Hg}) \\
\text { Mean arterial blood pressure }(\mathrm{mm} \mathrm{Hg}) \\
\text { Weight }(\mathrm{kg}) \\
24 \text { hour sodium excretion }(\mathrm{mmol}) \\
24 \text { hour potassium excretion }(\mathrm{mmol})\end{array}$ & $\begin{array}{r}110 \cdot 0 \\
64 \cdot 1 \\
79 \cdot 4 \\
64 \cdot 3 \\
88 \cdot 9 \\
63 \cdot 4\end{array}$ & $\begin{array}{r}111 \cdot 0 \\
64 \cdot 5 \\
80 \cdot 0 \\
64 \cdot 2 \\
108 \cdot 0 \\
63 \cdot 1\end{array}$ & $\begin{array}{r}0 \cdot 8 \\
0 \cdot 9 \\
0 \cdot 7 \\
0 \cdot 2 \\
12 \cdot 0 \\
2 \cdot 5\end{array}$ & $\begin{array}{r}108 \cdot 2 \\
62 \cdot 2 \\
77 \cdot 5 \\
60 \cdot 8 \\
69 \cdot 4 \\
67 \cdot 5\end{array}$ & $\begin{array}{r}109 \cdot 6 \\
61 \cdot 8 \\
77 \cdot 7 \\
60 \cdot 6 \\
105 \cdot 2 \\
64 \cdot 2\end{array}$ & $\begin{array}{l}1 \cdot 2 \\
1 \cdot 3 \\
1 \cdot 0 \\
0 \cdot 26 \\
18 \cdot 2 \\
3 \cdot 7\end{array}$ & $\begin{array}{r}113 \cdot 2 \\
63 \cdot 7 \\
80 \cdot 2 \\
63 \cdot 8 \\
95 \cdot 7 \\
60 \cdot 2\end{array}$ & $\begin{array}{r}112 \cdot 6 \\
64 \cdot 1 \\
80 \cdot 2 \\
63 \cdot 5 \\
91 \cdot 1 \\
56 \cdot 7\end{array}$ & $\begin{array}{l}0.8 \\
1.0 \\
0 \cdot 7 \\
0 \cdot 15 \\
14 \cdot 5 \\
2 \cdot 4\end{array}$ & $\begin{array}{r}113 \cdot 5 \\
62 \cdot 6 \\
79 \cdot 6 \\
62 \cdot 1 \\
90 \cdot 2 \\
61 \cdot 2\end{array}$ & $\begin{array}{r}112 \cdot 5 \\
62 \cdot 5 \\
79 \cdot 2 \\
61 \cdot 6 \\
78 \cdot 4 \\
57 \cdot 3\end{array}$ & $\begin{array}{c}1 \cdot 0 \\
1 \cdot 2 \\
0 \cdot 9 \\
0 \cdot 14^{\star} \\
17 \cdot 9 \\
3 \cdot 0\end{array}$ \\
\hline
\end{tabular}

${ }^{\star} \mathbf{p}<0.01$.

TABLE III-Effects of treatment, with estimated standard errors of differences

\begin{tabular}{|c|c|c|c|c|c|c|c|c|c|c|c|c|}
\hline & \multicolumn{6}{|c|}{ Low/low offspring } & \multicolumn{6}{|c|}{ High/high offspring } \\
\hline & \multicolumn{3}{|c|}{ Completers $(n=31)$} & \multicolumn{3}{|c|}{ Compliers $(n=16)$} & \multicolumn{3}{|c|}{ Completers $(n=35)$} & \multicolumn{3}{|c|}{ Compliers $(n=26)$} \\
\hline & $\begin{array}{l}\text { Slow } \\
\text { release } \\
\text { sodium }\end{array}$ & Placebo & $\begin{array}{c}\text { SE of } \\
\text { difference }\end{array}$ & $\begin{array}{l}\text { Slow } \\
\text { release } \\
\text { sodium }\end{array}$ & Placebo & $\begin{array}{c}\text { SE of } \\
\text { difference }\end{array}$ & $\begin{array}{l}\text { Slow } \\
\text { release } \\
\text { sodium }\end{array}$ & Placebo & $\begin{array}{c}\text { SE of } \\
\text { difference }\end{array}$ & $\begin{array}{l}\text { Slow } \\
\text { release } \\
\text { sodium }\end{array}$ & Placebo & $\begin{array}{c}\text { SE of } \\
\text { difference }\end{array}$ \\
\hline $\begin{array}{l}\text { Systolic blood pressure }(\mathrm{mm} \mathrm{Hg}) \\
\text { Diastolic blood pressure }(\mathrm{mm} \mathrm{Hg}) \\
\text { Mean arterial blood pressure }(\mathrm{mm} \mathrm{Hg}) \\
\text { Weight }(\mathrm{kg}) \\
24 \text { hour sodium excretion }(\mathrm{mmol}) \\
24 \text { hour potassium excretion }(\mathrm{mmol})\end{array}$ & $\begin{array}{r}110 \cdot 7 \\
63 \cdot 6 \\
79 \cdot 3 \\
64 \cdot 3 \\
128 \cdot 4 \\
63 \cdot 5\end{array}$ & $\begin{array}{r}110 \cdot 2 \\
65 \cdot 0 \\
80 \cdot 1 \\
64 \cdot 2 \\
68 \cdot 4 \\
62 \cdot 9\end{array}$ & $\begin{array}{l}0.82 \\
0.90 \\
0 \cdot 73 \\
0 \cdot 20 \\
6 \cdot 0 \\
2 \cdot 5\end{array}$ & $\begin{array}{r}109 \cdot 8 \\
61 \cdot 3 \\
77 \cdot 4 \\
60 \cdot 8 \\
125 \cdot 6 \\
65 \cdot 6\end{array}$ & $\begin{array}{r}108 \cdot 0 \\
62 \cdot 8 \\
77 \cdot 8 \\
60 \cdot 6 \\
49 \cdot 0 \\
66 \cdot 0\end{array}$ & $\begin{array}{l}1 \cdot 16 \\
1 \cdot 23 \\
1 \cdot 01 \\
0 \cdot 26 \\
5 \cdot 2 \\
3 \cdot 8\end{array}$ & $\begin{array}{r}113 \cdot 6 \\
63 \cdot 3 \\
80 \cdot 1 \\
63 \cdot 8 \\
130 \cdot 6 \\
61 \cdot 3\end{array}$ & $\begin{array}{r}112 \cdot 2 \\
64 \cdot 5 \\
80 \cdot 4 \\
63 \cdot 5 \\
56 \cdot 3 \\
55 \cdot 6\end{array}$ & $\begin{array}{l}0 \cdot 74 \\
0 \cdot 93 \\
0 \cdot 74 \\
0 \cdot 16 \\
7 \cdot 0 \\
2 \cdot 3^{\star}\end{array}$ & $\begin{array}{r}113 \cdot 8 \\
61 \cdot 8 \\
79 \cdot 1 \\
61 \cdot 9 \\
126 \cdot 1 \\
63 \cdot 2\end{array}$ & $\begin{array}{r}112 \cdot 2 \\
63 \cdot 3 \\
79 \cdot 6 \\
61 \cdot 8 \\
42 \cdot 8 \\
55 \cdot 3\end{array}$ & $\begin{array}{l}0.93 \\
1.1 \\
0.91 \\
0 \cdot 16 \\
6.9 \\
2 \cdot 7^{\star \star}\end{array}$ \\
\hline
\end{tabular}

${ }^{\star} p<0.05 ;{ }^{\star \star} p<0.01$

period with placebo (table III). There was an $84 \mathrm{mmol}$ difference in urinary sodium excretion between the two periods of the study but no significant difference in blood pressure or body weight. Urinary potassium excretion was $8 \mathrm{mmol}$ lower during the period with the placebo $(\mathrm{p}<0.01)$. The $95 \%$ confidence interval for the difference in mean arterial pressure during the period with placebo ranged from $1.4 \mathrm{~mm} \mathrm{Hg}$ lower to $2.4 \mathrm{~mm} \mathrm{Hg}$ higher.

Comparison of the fourth week with placebo with the fourth week with slow sodium showed no significant difference in mean arterial pressure in the low/low group $(78.6 v 78.7 \mathrm{~mm} \mathrm{Hg})$. In the high/high group mean arterial pressure was $1.7 \mathrm{~mm} \mathrm{Hg}$ higher during the period with low sodium intake. This was not significant.

\section{Discussion}

Population based studies at Tecumseh, Michigan, ${ }^{1920}$ have shown that when young people are selected on the basis of their parents' blood pressures the contrast in predisposition to the development of high blood pressure is greatest when parents belong either both to the top or both to the bottom of their age and sex specific blood pressure distribution. ${ }^{21}$ To obtain sufficient numbers of offspring our studies were based on thirds of the blood pressure distributions of the parents, with each high/high and low/low group representing about $11 \%$ of offspring in the population.

In our first study $62 \mathrm{high} / \mathrm{high}$ offspring had significantly higher systolic blood pressures than 54 low/low offspring. ${ }^{13}$ Body weight and sodium and potassium excretion were similar in both groups. Within the high/high group an analysis of the regression of systolic pressure on sodium excretion, based on six blood pressure measurements and seven 24 hour urine collections per person, showed a negative association ( -0.062 (SE 0.025)). A weakness of this analysis, and of other, smaller regression studies reporting a positive association between blood pressure and urinary sodium excretion, ${ }^{11}{ }^{12}$ is that each subject is observed at one, usually high, level of intake recorded over a short period of time. In this study we were able to compare blood pressure in each subject at two levels of sodium intake, each sustained over four weeks. The principal advantage of the double blind, randomised crossover design is that the effect of this change in sodium intake can be interpreted independently of the many confounding factors that operate in open studies of sodium restriction. On a practical note, it also allows randomisation to different sodium intakes of subjects living in the same household.

The study was concerned primarily with the effect of changes in sodium intake rather than their feasibility. Low sodium foodstuffs were provided, therefore, in association with intensive support and encouragement. In these special circumstances, and with participants who had proved their willingness by providing seven consecutive 24 hour specimens of urine, 56 of the 66 offspring who completed the study achieved sodium intakes below $100 \mathrm{mmol} /$ day during the period with placebo ( 33 below $50 \mathrm{mmol} /$ day). The greater non-compliance with the diet and tablets in the low/low group is probably explained by the need to approach a greater proportion of them, as there were fewer low/low $(n=74)$ than high/high offspring $(n=96)$ in the original population. In both groups the number of compliant offspring was about a quarter of the total.

The results show no difference in blood pressure between the two periods of the trial in either group of offspring, whether the analyses are based on whole groups or compliant subgroups. Although mean blood pressure (diastolic and one third pulse pressure) did not change, it was interesting that systolic pressure fell and diastolic pressure rose non-significantly in both groups during the period on placebo.

A potential confounding factor is the fall in potassium excretion during the period with placebo in the compliant high/high offspring. The reduction, however, was only $8 \mathrm{mmol}$. As much larger differences in potassium intake are required to produce very small changes in blood pressure in young people ${ }^{22}$ we think it unlikely that interpretation of the effect of the $84 \mathrm{mmol}$ difference in sodium excretion is confounded by this observation.

A consequence of having small numbers of offspring available for the study was the fairly large age range, from 11-42 years, mean 22 . To investigate the effect of age the data from the 26 compliant high/high offspring were reanalysed in two subgroups with ages above and below the median (mean ages $29 \cdot 2$ and 12.9 years). No differences in mean arterial pressure between the periods with slow sodium and placebo were observed in either the older $(88.2 v$ $88.0 \mathrm{~mm} \mathrm{Hg}$ ) or younger $(70.1 v 71.3 \mathrm{~mm} \mathrm{Hg})$ high/high offspring.

Although the main analyses are based on the mean of data on blood pressure collected weekly during the two four week periods of 
the study, comparison of blood pressures measured during the fourth week of both periods also shows no significant differences in blood pressure in either group. There is no suggestion from these data that a fall in blood pressure was becoming apparent by the fourth week with placebo.

The study provides no direct evidence of the long term effect of low sodium intake, but the results can be interpreted to some extent in relation to this question. Allowing for the greater acceptability of gradual adaptation to lower sodium intake, we consider it unlikely, on the basis of our experience, that intakes below $50 \mathrm{mmol} /$ day could be maintained for long except by strongly motivated subjects. Although it can be argued that a longer study might have shown an effect on blood pressure, the argument is weakened by the probability that maintenance of the required level of sodium intake is an impracticable goal in developed countries, except in the special circumstances of a research study or during infant feeding. ${ }^{23}$ By way of contrast short term randomised controlled trials of the effect of reducing intakes of fat, ${ }^{24}$ alcohol, ${ }^{25}$ and meat ${ }^{26}$ have showed reductions in the blood pressures of normotensive subjects.

These results will perhaps be compared with those of Skrabal $e t$ $a l,{ }^{27}$ who studied 62 medical students aged 20-25 for two weeks on their usual diet and two weeks on a low sodium diet; the low sodium diet was provided by a hospital dietetic kitchen. In 28 subjects with a reported family history of hypertension mean arterial blood pressure fell by $3.3 \mathrm{~mm} \mathrm{Hg}$ during the period of low sodium intake, compared with a fall of $0.7 \mathrm{~mm} \mathrm{Hg}$ in 34 subjects without such a history. The difference between these results and ours may partly be explained by the greater change of sodium intake in the study of Skrabal et al from 199 to $36 \mathrm{mmol} /$ day. In view of the open design and the possible effects of other dietary changes, however, this study cannot be interpreted solely on the basis of a change in sodium intake.

These studies, based on complete ascertainment of blood pressures in a single population, careful sampling of positive and negative family histories, characterisation of sodium intakes by seven consecutive 24 hour collections of urine, and comparison, using a double blind, randomised controlled crossover design, of blood pressures during two four week periods with mean sodium intakes below $50 \mathrm{mmol}$ and above $120 \mathrm{mmol} /$ day, provide a direct test of the hypothesis that subjects vary in their blood pressure response to dietary sodium.

The finding of no association between dietary sodium and blood pressure in either group of offspring provides a strong rebuttal to previous studies, with shorter duration and less rigorous design, which have suggested that offspring with a family history of high blood pressure are more susceptible to dietary sodium. The study does not disprove the hypothesis of susceptibility. It did not investigate the long term effect of lowering sodium intake, the effect in younger ${ }^{23}$ and older persons, ${ }^{28}{ }^{29}$ or the effect of changes in sodium intake outwith the range $50-120 \mathrm{mmol} /$ day. Nor does it exclude the possibility that other subgroups may be susceptible to high sodium intake-for example, young persons with high age and sex specific blood pressure levels irrespective of their family history.

More important than these theoretical possibilities, however, are several practical issues. What matters is not whether there is a causal relation between dietary sodium and blood pressure but whether the relation, if it exists, can provide a worthwhile basis for prevention. If the association is weak, or only evident at sodium intakes that are difficult to achieve, as suggested by these studies, reduction in sodium intake below $120 \mathrm{mmol} /$ day may make only a marginal contribution to the prevention of high blood pressure.

This work was supported by the British Heart Foundation and the Medical Research Council. We thank Mr Tony Thomas and Dr Tony Ames of Neath General Hospital and Mr C J Scotland and Professor Gemmel Morgan of Glasgow Royal Infirmary for analyses of urinary electrolytes; CIBA laboratories for supplies of slow release sodium and placebo tablets; Dr Tim Helme, research registrar, for help with fieldwork; Dr A F Lever for comments on an earlier draft of this paper; colleagues at the Medical Research Council Epidemiology and Medical Care Unit, Northwick Park Hospital, Middlesex, for their help and advice; and staff, patients, and their families at Glyncorrwg Health Centre for their cooperation with these studies.

\section{References}

1 Watt GCM, Foy CJW. Dietary sodium and arterial pressure: problems of studies within a single population. F Epidemiol Community Health 1982;36:197-201.

2 Lever AF, Beretta-Piccoli C, Brown JJ, et al. Sodium and potassium in essential hypertension. Br Med f 1981;283:463-8.

3 Anonymous. Genes, environment and hypertension. [Editorial.] Lancet 1983;i:681-2.

4 Ambrosioni E, Costa FV, Montebugnoli L, et al. Intralymphocottic sodium concentration as an index of response to stress and exerr'se in young subjects with borderline hypertension. $\mathrm{Clin} \mathrm{Sci}$ index of responset

5 Bianchi G, Cusi D, Barlassina C, el al. Renal dysfunction as a possible cause of essentia hypertension in predisposed subjects. Krdney Int 1983;23:870-5

6 Cooper R, Miller K, Trevisan M, et al. Family history of hypertension and red cell cation transport in high school students. F Hypertension 1983;1:145-52.

7 Devynck M, Pernollet M, Rosenfeld J, et al Measurements of digitalis-like compound in plasma application in studies of essential hypertension. Br Med f 1983;287:631-4

$8 \mathrm{Grim}$ CE, Luft FC, Miller JZ, et al. Effects of sodium loading and depletion in normotensive firstdegree relatives of essential hypertensives. $\mathcal{F}$ Lab Clin Med 1979;94:764-71.

9 Nara $Y$, Kihara $M$, Kanbe T, et al. Sodium-accelerated platelet aggregation in men predisposed to essential hypertension. Clin Sct 1982;63:391-3s

10 Skrabal F, Herholz H, Neumayr $M$, et al. Salt sensitivity in humans is linked to enhanced sympathetic responsiveness and to enhanced proximal tubular reabsorption. Hypertenston 1984;6:152-8

11 Pietinen PI. Wong O, Altschul AM. Electrolyte output, blood pressure and family history of hypertension. Am 7 Clin Nutr 1979;32:997-1005.

12 Strazzullo P, Cappuccio FP. Trevisan M, et al. Association between blood pressure, dietary salt intake and family history of hypertension in a five year follow-up study. $f$ Hyperiension 1983:1(suppl 2): 159-61

13 Watt GCM, Fov CJW, Hart JT. Comparison of blood pressure, sodium intake, and other variables in offspring with and without a family history of high blood pressure. Lancet 1983;:1:1245-8.

in offspring with and without a family history of high blood pressure. Lancet 1983;1: 12
4 Freis ED Salt, volume and the prevention of hypertension. Circulation 1976;53:589-95.

14 Freis ED. Salt, volume and the prevention of hypertension. Curculation $1976 ; 53.589-95$.
15 Prior IAM. Evans JG, Harvev HPB, et al. Sodium intake and blood pressure in two Polynesian

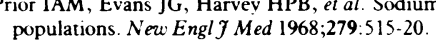

16 Beaglehole R, Eyles E, Salmond C, et al. Blood pressure in Tokelauan children in two contrastin environments. Am f Epidemiol 1978;108:283-8.

17 Hart JT. The distribution of mortality from coronary heart disease in south Wales. 7 Row Coll Gen Pract 1970;19:258-68.

18 Hart JT. Hypertension. London: Churchill Livingstone, 1980

19 Deutscher S, Epstein FH, Kjelsberg M. Familial aggregation of factors associated with coronary heart disease. Circulation 1966;33:911-24

20 Higgins MW, Keller JB, Metzner HL, Moore F, Ostrander LD Jr. Studies of blood pressure in Tecumseh, Michigan. II. Antecedents in childhood of high blood pressure in voung adults. Hypertension 1980;2(42):117-23.

21 Watt GCM. Design and interpretation of studies comparing individuals with and without a family

history of high blood pressure. $\mathcal{J}$ Hypertension (in press).
22 Khaw KT, Thom S. Randomised double blind cross-over trial of potassium on blood pressurc in normal subjects. Lancet 1982 ;ii:1127-30.

23 Hofman A, Hazebroek A, Valkenburg HA. A randomised trial of sodium intake and blood pressure in newborn infants. FAMA 1983;250:370-3.

24 Puska P, Iacono JM, Nissinen A, et al. Controlled, randomised trial of the effect of dietary fat on blood pressure. Lancet 1983;i: 1-5.

25 Puddey IB, Beilin LJ, Vandorgen R, et al. The effect of moderation of alcohol consumption on blood pressure in man: a randomised controlled intervention study. Clin Exp Pharmacol Physiol (in press).

26 Rouse IL, Beilin L, Armstrong BK, et al. Blood-pressure-lowering effect of a vegetarian die controlled trial in normotensive subjects. Lancet 1983;i:5-10.

27 Skrabal F, Hamberger L, Shonegger J, et al. Normotensives with heredity of hypertension are salt sensitive. In: Ghione S, ed. Individual susceptibility to salt intake and arterial hypertension: report of an EC workshop, Pisa, Italv, 1984. Wageningen: Stichtung Nederlands Institut voor de Boeding, 1985: 159-68. (Eur-Nut Report 3.)

28 Gudmundsson $\mathrm{O}$, Berglund $\mathrm{G}$, Herlitz $\mathrm{H}$, et al. Influence of age on the response to increased salt intake: effects of blood pressure and sodium in erythrocytes. F Hypertension 1983;1(suppl 2): $15-7$.

29 Myers J, Morgan T. The effect of sodium intake on the blood pressure related to age and sex. Clin Exp Hypertension [A] 1983;5(1):99-118.

(Accepted 11 September 1985)

\section{YEARS AGO}

At a recent meeting of the Académie de Médecine, $M$. Tarnier showed two infants that had been artificially reared in his service at the Maternity o Hospital. The couveuse, or hatching-machine, is kept at a temperature of $30^{\circ}$ I and $39^{\circ}$ Centigrade $\left(93^{\circ}\right.$ and $98^{\circ} \mathrm{Fahr}$.). The more the birth is premature, the higher is the degree of temperature maintained. Since last October, M. $N$ Tarnier has fed these artificially reared infants by a method known as gavage. An India-rubber bougie, with a glass capsule fitted on to it, is introduced into $\omega$ the infant's stomach; the milk is then poured down, and the bougie is withdrawn the moment the food reaches the stomach, in order to prevent 0 regurgitation. After testing different forms of food, Mr. Tarnier believes human milk to be the best, but a very small quantity is sufficient; otherwise, the babes have acute œdema, resulting from over nutrition. The two children shown at the meeting of the Académie were born at the sixth month; one weighed 1,020 grammes at time of birth; its weight afterwards fell to 850 grammes, and subsequently reached 955 . It was artificially fed every hour with at first eight grammes of human milk; the fourth day after birth, 16 grammes were given to it, and shortly afterwards it was made to suckle at the breast. It was six weeks old when exhibited, and in excellent health. The second example was two months old, and weighed 1,500 grammes. (British Medical fournal 1885;ii:405.) . . .

.

